\title{
Problems of Implementation of the European Convention on Human Rights by Imposition of Administrative Sanctions
}

\author{
Elizaveta A. Saponchik* \\ Siberian Federal University \\ 79 Svobodny, Krasnoyarsk, 660041, Russia
}

Received 22.05.2017, received in revised form 09.06.2017, accepted 15.06.2017

The present article investigates the problems of application of certain provisions of the European Convention for the Protection of Human Rights and Fundamental Freedoms (hereinafter referred to as ECHR) at imposition of administrative sanctions. The author analyzes the peculiarities of the approach of the European Court of Human Rights (hereinafter referred to as ECtHR) to disciplinary cases and investigates the criteria of application of the appropriate provisions of the Conventions to the cases based on the offence of administrative relations. The research leads the author to the conclusion on the influence of the ECtHR approach on the procedural aspect of public competence in the context of public prosecution.

Keywords: administrative offence, case of Engel and others v. the Netherlands, case of Ozturk v. Germany, case of Kasparov and others v. Russia, European Court of Human Rights, European Convention for the Protection of Human Rights and Fundamental Freedoms, Engel criteria.

DOI: 10.17516/1997-1370-0100.

Research area: law.

\section{Introduction to the problem}

According to Part 4 Article 15 of the Constitution of the Russian Federation, the universally-recognized norms of international law and international treaties and agreements of the Russian Federation shall be a component part of its legal system. If an international treaty or agreement of the Russian Federation fixes other rules than those envisaged by law, the rules of the international agreement shall be applied. Professor Marochkin S.Yu. emphasized the importance of Article 15 of the RF Constitution: “....It is not an ordinary constitutional regulation; it contains one of the underlying constitutional principles of Russia formulated in Chapter One of the Constitution"1.

A similar provision is included into the Code of the Russian Federation on Administrative Offences, particularly, into Part 2 Article 1.1. As we see from the quoted regulations, it is impossible to study the issues of imposing any administrative sanctions without investigation of the relevant international legal acts².

In this field, the most important international treaty is the European Convention for the

(C) Siberian Federal University. All rights reserved

* Corresponding author E-mail address: s.Lisa@list.ru 
Protection of Human Rights and Fundamental Freedoms of November 4, 1950, also recognized by the Russian Federation. The purpose of the Convention is to create a mechanism for protection of personality from unlawful deeds of the state, as well as forming a positive obligation of the state to create and to maintain conditions required for the implementation of the Convention. The execution of the said obligations is a part of administrative activity of the state in the public and private spheres.

\section{Problem setting}

First of all, it is worth noticing that such term as disciplinary offence is not used in the European Convention for the Protection of Human Rights and Fundamental Freedoms. As for various procedural guarantees (right to a fair and public trial within reasonable time before an independent and impartial tribunal, presumption of innocence), according to the Convention text, they refer only to the sphere of criminal law. Does it mean that the Convention is not applicable to cases derived from disciplinary offence? It is hardly possible to imagine a situation when a disciplinary case would be completely beyond the jurisdiction of the European Court of Human Rights!

For this reason, the Court has developed a special approach to applying the Convention to disciplinary cases.

Most frequently, persons imposed with a administrative sanctions make a reference to the fact that the order of imposing the administrative sanction contradicted requirements of Article 6 of the Convention establishing important guarantees for the accused. For this reason, the central question to be answered is the question of applicability of Article 6 of the Convention to disciplinary cases.

The standard answer of the defendant state to the claims derived from administrative legal relations is based on ratione materie, i.e. on the irrelevancy of administrative trial to Article 6 of the Convention on Human Rights. The European Court answers to the argument as follows: "If the contracting states could, at their own discretion, qualify the offence as a disciplinary infraction instead of a criminal offence, or if they could prosecute the perpetrator of the "mixed" crime disciplinarily, not criminally, the action of the basic provisions of Articles 6 and 7 would have been subject of their sovereign will. Such expansion would lead to results incompatible with the purposes and tasks of the Convention. For this reason, in accordance with Article 6 and even without reference to Articles 17 and 18, the Court may see that disciplinary prosecution does not replace the criminal one in any possible way".

To ensure applicability of Article 6 of the Convention to disciplinary cases, the European Court has developed a number of criteria. The resolutions of the European Court (case of Adolf v. Austria) imply that the term of "criminal charge" used in Article 6 of the Convention has an autonomous meaning not depending on any classifications on the national legal systems of the Contracting States. Existing researchers underline that the European Court uses the "criminal charge" term in the broadest way4.

Therefore, offenses classified as disciplinary by national law, may be classified as "criminal" by the Convention. As the Court emphasizes, leaving exclusion of such offences from the scope of the Convention to the discretion of the states would have been incompatible with its tasks and purposes $^{5}$.

\section{"Engel Criteria"}

In order to investigate all of these criteria, let us return to the underlying case of Engels and others v. the Netherlands ${ }^{6}$. The criteria were first formulated in this case judgment. 
First of all, it is required to determine whether relevant legal regulations belong to criminal, disciplinary law, or both concurrently. However, it is not more than the starting point, not the major criterion. As stated by the Court in the Engel and others v. the Netherlands judgment, these indications so afforded have only a formal and relative value and must be examined in the light of the common denominator of the respective legislation of the various Contracting States.

The second criterion is the very nature of the offence. This criterion bears a much more important meaning. It includes consideration of the following issues: generally binding nature of the regulation, consideration of the case by a national law enforcement body, compensational or penal character of the applied liability, dependence of the punishment from the establishment of guilt, whether the offence leads to criminal conviction as well as classification of the offence in other Contracting States.

The third criterion is the degree of severity of the potential punishment. For instance, in the case of Engel and others v. the Netherlands the claimant was provisionally detained in strict arrest for two days. The European Court refused to refer this punishment to the criminal sphere as, according to the Court, it was too short. Moreover, upon the end of the proceedings the claimant was not subject to any deprivation of freedom since, according to the national court, he had already completed the sentence it during the provisional detention?

As for the practical application of the listed criteria, both alternative and cumulative approaches are acceptable. Thus, the presence of one criterion is usually sufficient. Nevertheless, if the alternative approach does not lead to a firm conclusion, cumulative approach may be applied. This conclusion was drawn by the European Court in the judgment for the case of Lutz v. Germany ${ }^{8}$.
Subsequently, the three "Engel criteria" were developed by means of expansion of the "criminal" sphere onto disciplinary offences. From the European Court's point of view, such offences are classified as universal, i.e. "criminal".

Currently the European Court uses these criteria for the establishment of applicability of Article 6 of the Convention to cases derived from disciplinary offences. It is important to understand that the ECtHR did not intend and it still does not intend to obstruct the technical borders of national criminal law established by the State, which is still entitled to draw the limits of its criminal codes at its own discretion, to exclude some petty offences, criminal and non-criminal sanctions from the scope of its applicability ${ }^{9}$. On the contrary, in the underlying case of Engel v. the Netherlands the European Court reminds of the state sovereignty once again: "The Convention without any doubt allows the States, in the performance of their function as guardians of the public interest, to maintain or establish a distinction between criminal law and disciplinary law, and to draw the dividing line, but only subject to certain conditions ${ }^{10 "}$.

\section{Case of Ozturk v. Germany}

To understand the way the European court draws the division between disciplinary and criminal offences it is worth investigating some famous judgments of the Court.

Particularly, the case of Ozturk v. Germany is of great interest. This case concerns criminal and legal nature of disciplinary offences and lies in the scope of criminal matter, i.e. the criminal sphere, which does not and cannot depend on whether the legislator referred to the deeds subject to public sanctions as to any criminal offenses, petty offenses or disciplinary offences ${ }^{11}$.

Driving his car, the claimant caused a traffic accident leading to a damage of another car of 
5000 Deutschemarks. According to the Law on disciplinary offence, Ozturk was prescribed the fine of $60 \mathrm{DM}$ for the violation of traffic rules. The claimant disputed the decision of the state in court. As a result of the trial Ozturk attended with an interpreter, the claimant decided to withdraw the lawsuit. The court resolved that Ozturk was to cover legal expenses including the interpreter's fee.

The European court was to decide whether the claimant was deprived of the right for free interpreter's assistance in breach of Article 6 of the Convention. As it has been mentioned above, the article is only applicable to criminal offenses.

In its resolution, the Court re-confirmed the "autonomy" of the "criminal" term and then investigated whether the disciplinary offence could be classified as such from the point of view of the Convention. The Court used the criteria formulated in the case of Engel.

As far as German law is concerned, the claimant had committed a disciplinary offense. However, as emphasized by the Court, this fact only bears formal character and is relatively relevant. The nature of the offence as such, investigated in connection with the imposed sanction, is more relevant. The Court established that offenses of criminal law tend to cause implementation of fines and deprivation of freedom. Moreover, in the majority of Contracting States this offence is still classified as criminal.

As for the sanctions, in this very case their nature was repressive and preventive, thereby causing the vision of the offence as criminal in the light of the Convention. This way, Ozturk was not guaranteed free assistance of an interpreter foreseen by Part 3 "e" Article 6 of the Convention in the event of charge with a criminal offence ${ }^{12}$.

In other words, the European Court arrived at the conclusion that the State was entitled to decriminalize and draw some deeds beyond the limits of formal criminal law, terminologically indicating them at its own discretion, but retaining the obligation to preserve all the guarantees foreseen for criminal cases (presumption of innocence, right to defence, right to appeal etc.). Otherwise, from the point of view of the guarantees established by Article 6 of the European Convention, it would have been extremely dangerous "had the states been allowed to withdraw a whole category of offences from the scope of this article for being minor"13.

\section{Kasparov and others v. the Russian Federation}

As proven by practice, the problem of distinguishing between criminal and disciplinary offences is still one of the most complicated ones for the majority of post-Soviet countries including Russia ${ }^{14}$. A number of judicial acts on cases of disciplinary offences have been disputed at the European Court by Russian citizens. One of these cases is that of Kasparov and others v. the Russian Federation ${ }^{15}$.

The first claimant, Kasparov, was detained and brought to the police station. On the day of detention, he appeared before the judge of the peace. He was accused of having breached the established order of organizing social events, an offence foreseen by Part 2 Article 20.2 of the Code of the Russian Federation on Administrative Offences. The trial was scheduled for 17:30 of the same day. The claimant lodged two petitions of adjourning the case to prepare appropriate defence. Both petitions were rejected for the reason of minor volume of the case (5 pages). The judge postponed the trial of the case for 45 minutes, and then for 20 minutes more.

At 18:30 the judge began studying the case. The lawyer of the claimant lodged a petition on permission of public into the court room.

However, no one could enter the court room since the building had been secured by the police. 
The judge satisfied the petition by stating that the trial was public.

At the beginning of the trial the claimant lodged a motion to summon and question six witnesses. The judge rejected the motion as, in her opinion, summoning witnesses before interrogation of the claimant and the police officers was too early. After the police officers had been interrogated, the claimant lodged a motion to summon the witnesses again. The motion was rejected for the reason that the said persons had not been mentioned in the police protocol, and that the circumstances of the case were clear enough to draw conclusions.

Later the claimant attempted to dispute the judgment on imposition administrative sanctions on him, but the court of appeal upheld the judgment. The claimant addressed the European Court with the claim on the breach of Part 1, Part 2 "b", "d" Article 6 of the Convention.

Analysing acceptability of the claim, the Court applied the three criteria again. First of all, the breaches of the order of organizing public events are regulated by disciplinary law. In some legal systems, criminal law also covers offences of criminal nature but too trivial to be regulated by criminal law.

In such cases, indication of the national law is not final; the nature of the offence matters much more. Article 20.2 of the Code of the Russian Federation on Administrative Offence, foreseeing liability for participation in an unauthorized public event, is applicable to breaches of social order and to regulation of any public events. The legal regulation violated by the claimant is applicable to all citizens, not a certain group of people with a special status.

The Court noticed that the claimant had been imposed a maximum fine of 25 Euro, which is the maximum penalty for the article. In its nature, this penalty is not a material compensation, but a means of deterrence and punishment, which is typical of a criminal penalty.

The Court also noticed that the claimant had been detained and had spent over two hours at the police station. For recognition of any case as a criminal one, any form of deprivation of freedom is relevant. The claimant had been imposed a disciplinary detention as per Article 27.3 of the Code of the Russian Federation on Administrative Offence having a more distinctive criminal nature than Article 27.2 of the Code.

Having taken the listed arguments into account, the Court resolved to classify the committed offence as a "criminal" one. The claim was recognized as legitimate ${ }^{16}$.

Concluding the analysis of the European Court practice analysis, let us remark that the European standards of criminal proceedings may also be applied to disciplinary proceedings ${ }^{17}$.

\section{Conclusions}

The research brings us to the following conclusions.

Firstly, the Court helps the Contracting States draw a division line between criminal and disciplinary law. For this reason, the position of the Court does not mean any fundamental unacceptance of disciplinary offences. Nevertheless, the majority of disciplinary cases still appear to be in the "criminal sphere".

Secondly, the European Court's approach to disciplinary offence interpretation influences, first of all, the procedural aspect of state and governmental authorities in the context of public prosecution. It is manifested in the fact that in each and every case the European Court resolves the issue on the possibility of providing guarantees for fair and public trial of the disciplinary case. 
1 Marochkin, S. Yu. (1998). Deystvie norm mezhdunarodnogo prava v pravovoy sisteme Rossiyskoy Federatsii [International Law in the Courts of the Russian Federation: Practice of Application]. M.: Norma, Infra-M. P. 330.

2 Bakhrakh, D.N., Burkov, A.L. (2010). The European Convention on Human Rights in Russian law and practice of ministerial inquiry. In Journal of Russian law, (6), 67-77.

Panova, I.V. (2012). Administrative law in cases of the European Court of Human Rights. In The Law, (2), 35-54.

4 Bakhrakh, D.N., Burkov, A.L. (2010). The European Convention on Human Rights in Russian law and practice of ministerial inquiry. In Journal of Russian law, (6), 67-77.

Adolf v. Austria (1982). Available at: http://hudoc.echr.coe.int/app/conversion/pdf/?...ECHR... (accessed 16 March 2017) Adolf v. Austria (1982). Available at: http://hudoc.echr.coe.int/app/conversion/pdf/?...ECHR... (accessed 16 March 2017)

Engel and others v. The Netherlands (1976). Available at: http://www.echr.ru/documents/doc/2461444/2461444.htm (accessed 16 March 2017)

8 Lutz v. Germany (1987). Available at: http://www.echr.ru/documents/doc/2461415/2461415.htm (accessed 16 March 2017)

9 Golovko, L.V. (2013). Interrelation of criminal and administrative offences in the context of criminal matters conception. In Institute of law and public politics, (5), 45-52.

10 Engel and others $v$. The Netherlands (1976), Available at: http://www.echr.ru/documents/doc/2461444/2461444.htm (accessed 16 March 2017)

11 Klepitskii, I.A. (2000). Criminal act, administrative violation and sanction in Russia in the context of ECHR. In State and law. (3), 65-70.

12 Ozturk v. Germany (1984). Available at: http://europeancourt.ru/resheniya-evropejskogo-suda-na-russkom-yazyke/oztyurk-protiv-germanii-ozturk-v-germany-postanovlenie-evropejskogo-suda/ (accessed 16 March 2017)

13 Golovko, L.V. (2013). Interrelation of criminal and administrative offences in the context of criminal matters conception. In Institute of law and public politics, (5), 45-52.

14 Golovko, L.V. (2013). Interrelation of criminal and administrative offences in the context of criminal matters conception. In Institute of law and public politics, (5), 45-52.

15 Kasparov and others v. Russia (2013). Available at: http://europeancourt.ru/tag/kasparov-and-others-v-russia/ (accessed 16 March 2017)

16 Kasparov and others v. Russia (2013). Available at: http://europeancourt.ru/tag/kasparov-and-others-v-russia/ (accessed 16 March 2017)

17 Pankova, O.A. (2014). Administrativnye pravonarusheniia v kontekste Konventsii o zaschite prav cheloveka $i$ osnovnykh svobod [Administrative cases in the context of ECHR]. M.: Statut. P. 405.

\section{References}

Adolf v. Austria (1982). Available at: http://hudoc.echr.coe.int/app/conversion/pdf/?...ECHR... (accessed 16 March 2017)

Bakhrakh, D.N., Burkov, A.L. (2010). The European Convention on Human Rights in Russian law and practice of ministerial inquiry, In Journal of Russian law, (6), 67-77.

Engel and others v. The Netherlands (1976). Available at: http://www.echr.ru/documents/ doc/2461444/2461444.htm (accessed 16 March 2017)

Golovko, L.V. (2013). Interrelation of criminal and administrative offences in the context of criminal matters conception. In Institute of law and public politics, (5), 45-52.

Klepitskii, I.A. (2000). Criminal act, administrative violation and sanction in Russia in the context of ECHR. In State and law. (3), 65-70.

Marochkin, S.Yu. (1998). Deystvie norm mezhdunarodnogo prava v pravovoy sisteme Rossiyskoy Federatsii [International Law in the Courts of the Russian Federation: Practice of Application]. M.: Norma, Infra-M. P. 330.

Kasparov and others v. Russia (2013). Available at: http://europeancourt.ru/tag/kasparov-andothers-v-russia/ (accessed 16 March 2017)

Lutz v. Germany (1987). Available at: http://www.echr.ru/documents/doc/2461415/2461415.htm (accessed 16 March 2017)

Ozturk v. Germany (1984). Available at: http://europeancourt.ru/resheniya-evropejskogo-sudana-russkom-yazyke/oztyurk-protiv-germanii-ozturk-v-germany-postanovlenie-evropejskogo-suda/ (accessed 16 March 2017)

$$
-936-
$$


Pankova, O.A. (2014). Administrativnye pravonarusheniia v kontekste Konventsii o zaschite prav cheloveka i osnovnykh svobod [Administrative cases in the context of ECHR]. M.: Statut. P. 405.

Panova, I.V. (2012). Administrative law in cases of the European Court of Human Rights. In The Law, (2), 35-54.

\title{
Проблемы реализации \\ Конвенции о правах человека \\ при привлечении к административной \\ ответственности
}

\author{
Е.А. Сапончик \\ Сибирский федеральный университет \\ Россия, 660041, Красноярск, пр. Свободный, 79
}

В данной статье рассмотрены проблемы применения некоторых положений Конвенции о защите прав человека и основных свобод (далее - Конвенция) при привлечении к административной ответственности. Проанализированы особенности подхода, используемого Европейским судом по правам человека (далее - ЕСПЧ) в делах о привлечении к административной ответственности, рассмотрены критерии, определяюшие возможность применения соответствующих положений Конвенции к делам, возникающим из административных правоотношений. На основе проведенного исследования автор делает вывод о влиянии подхода ЕСПЧ прежде всего на процессуальную сторону осуществления государственно-властных полномочий в контексте публичного обвинения.

Ключевые слова: административное правонарушение, дело «Энгель и другие против Нидерландов», дело «Озтюрк против Германии», дело «Каспаров и другие против России», Европейский суд по правам человека, Европейская конвенщия о защите прав человека и основных свобод, критерии Энгеля.

Научная спещиальность: 12.00.00 - юридические науки. 